\title{
Largest global shark biomass found in the northern Galápagos Islands of Darwin and Wolf
}

Pelayo Salinas de León, David Acuña-Marrero, Etienne Rastoin, Alan M Friedlander, Mary K Donovan, Enric Sala

Overfishing has dramatically depleted sharks and other large predatory fishes worldwide except for a few remote and/or well-protected areas. The islands of Darwin and Wolf in the far north of the Galapagos Marine Reserve (GMR) are known for their large shark abundance, making them a global scuba diving and conservation hotspot. Here we report quantitative estimates of fish abundance at Darwin and Wolf over two consecutive years using stereo-video surveys, which reveal the largest reef fish biomass ever reported (17.5 $t \mathrm{th}^{-1}$ on average), consisting largely of sharks. Despite this, the abundance of reef fishes around the GMR, such as groupers, has been severely reduced because of unsustainable fishing practices. Although Darwin and Wolf are within the GMR, they were not fully protected from fishing until March 2016. Given the ecological value and the economic importance of Darwin and Wolf for the dive tourism industry, the current protection should ensure the long-term conservation of this hotspot of unique global value. 


\section{Largest global shark biomass found in the northern Galapagos Islands of Darwin and Wolf}

2 Salinas-de-León P 1,* , Acuña-Marrero D ${ }^{1}$, Rastoin E ${ }^{1}$, Friedlander AM ${ }^{2,3}$, Donovan MK ${ }^{3}$, Sala $3 \mathrm{E}^{2}$

$4{ }^{1}$ Department of Marine Sciences, Charles Darwin Research Station, Puerto Ayora, Galapagos Islands,

5 Ecuador

$6 \quad{ }^{2}$ Pristine Seas, National Geographic Society, Washington, DC, USA

$7 \quad{ }^{3}$ Fisheries Ecology Research Lab, University of Hawai’i at Manoa, Honolulu, HI, USA

8 * Author to whom correspondence should be addressed. Email:pelayo.salinas@,fcdarwin.org.ec;

9 Tel.:+593997478133

\section{Abstract}

12 Overfishing has dramatically depleted sharks and other large predatory fishes worldwide except

13 for a few remote and/or well-protected areas. The islands of Darwin and Wolf in the far north of 14 the Galapagos Marine Reserve (GMR) are known for their large shark abundance, making them 15 a global scuba diving and conservation hotspot. Here we report quantitative estimates of fish 16 abundance at Darwin and Wolf over two consecutive years using stereo-video surveys, which 17 reveal the largest reef fish biomass ever reported (17.5 $\mathrm{t} \mathrm{ha}^{-1}$ on average), consisting largely of 18 sharks. Despite this, the abundance of reef fishes around the GMR, such as groupers, has been severely reduced because of unsustainable fishing practices. Although Darwin and Wolf are within the GMR, they were not fully protected from fishing until March 2016. Given the ecological value and the economic importance of Darwin and Wolf for the dive tourism industry, the current protection should ensure the long-term conservation of this hotspot of unique global value. 
34 Overfishing has reduced biomass of most sharks and other large predatory fishes worldwide by over 90\% (Baum et al., 2003; Myers \& Worm, 2003; Ward-Paige et al., 2010), and even remote locations have been severely impacted (Dulvy et al., 2008; Sibaja-Cordero, 2008; Graham, Spalding \& Sheppard, 2010; White et al., 2015). One in four species of cartilaginous fishes is now threatened with extinction due primarily to overexploitation and habitat loss (Dulvy et al., 2014). The systematic removal of sharks from marine ecosystems has negative effects that propagate throughout the entire food web (Bascompte, Melián \& Sala, 2005; Myers et al., 2007; Heithaus, Wirsing \& Dill, 2012).

Sharks and other top reef predators dominate healthy marine ecosystems, so that the traditional fish biomass pyramid is inverted in these increasingly rare areas (Friedlander \& DeMartini, 2002; Sandin et al., 2008; Sandin et al., 2015). However, only a few localities worldwide still maintain large abundances of top predatory fishes due to either being remote and unfished, or having recovered after full protection from fishing (Sandin et al., 2008; Aburto-Oropeza et al., 2011; Graham \& McClanahan, 2013; Friedlander et al., 2014a). The small number of scientific studies on relatively pristine ecosystems limits our ability to establish true baselines of sharks and other large predatory fish abundance and this restricts our capacity to determine realistic recovery targets for degraded ecosystems (McClenachan et al., 2012; Sala 2015), thus perpetuating the shifting baseline syndrome (Pauly, 1995; Jackson, 2010). The establishment of marine protected areas (MPAs), especially no-take areas (NTA) where all forms of fishing are prohibited, have been shown to be one of the most successful management tools to confront global ecosystem degradation (Halpern \& Warner, 2002; Lester et al., 2009; Edgar et al., 2014). A growing body of literature supports the positive effects of NTA, which includes substantial recoveries in fish abundance and biomass (Aburto-Oropeza et al., 2011; Eddy, Pande \& Gardner, 2014); a greater biomass, abundance and size of top predators inside reserves than in nearby fished areas (see review by Lester et al., 2009); increase in abundance and biomass in nearby areas due to the spill-over of adults and/or larvae (Goñi et al., 2008; Halpern, Lester \& Kellner, 2009; Christie et al., 2010), and shifts in species composition and trophic cascades that result in the restoration of entire ecosystems (Babcock et al., 1999, 2010; Shears \& Babcock, 2002, 2003). Furthermore, a recent analysis across 87 sites globally revealed that conservation benefits of MPAs increase exponentially when reserves are no take, well enforced, old, large and isolated 64 (Edgar et al., 2014).

65

The Galapagos Islands are known worldwide for its iconic terrestrial fauna and flora, due in large part to a young Charles Darwin who sailed to these islands in 1835 (Darwin, 1839). While Galapagos giant tortoises, Darwin's finches, and mocking birds have received much of the attention since Darwin's visit, the underwater Galapagos remains under-studied and largely unknown compared to terrestrial ecosystems. Galapagos is the only tropical archipelago in the world at the cross-roads of major current systems that bring both warm and cold waters. From the northeast, the Panama Current brings warm water; from the southeast the Peru current bring cold water; and from the west, the subsurface equatorial undercurrent (SEC) also bring cold water from the deep (Banks, 2002). The SEC collides with the Galapagos platform to the west of the Islands of Fernandina and Española, producing very productive upwelling systems that are 
75

76

77

78

79

80

81

82

83

84

85

86

87

88

89

90

91

92

93

94

95

96

97

98

99

100

101

102

103

104

105

106

107

108

109

110

111

112

113

114

115

116

the basis of a rich food web that supports cold water species in a tropical setting like the endemic Galapagos penguin (Spheniscus mendiculus) (Edgar et al., 2004). The oceanographic setting surrounding Galapagos results in a wide range of marine ecosystems and populations, that includes from tropical species like corals or reef sharks to temperate and sub-Antarctic species like the Galapagos fur seal (Arctocephalus galapagoensis) or the waived albatross (Phoebastria irrorata).

The far northern islands of Darwin and Wolf in the 138,000 $\mathrm{km}^{2}$ Galapagos Marine Reserve (GMR) represent a unique 'hotspot' for sharks and other pelagic species (Hearn et al., 2010, 2014; Acuña-Marrero et al., 2014; Ketchum et al., 2014a). Most of the studies around this area have focused on the migration of scalloped hammerhead sharks (Sphyrna lewini) and other sharks species between Darwin and Wolf and other localities in the Eastern Tropical Pacific (Hearn et al., 2010; Bessudo et al., 2011; Ketchum et al., 2014a). An ecological monitoring program has visited the islands over the past 15 years with a strong sampling focus to survey reef fishes and invertebrate communities (Edgar et al., 2011). However, no study to date has examined extensively the abundance, size, and biomass of sharks and other large predatory fishes around Darwin and Wolf. We conducted two expeditions to Darwin and Wolf in November 2013 and August 2014 to establish comprehensive abundance estimates for shark and predatory fish assemblages at Darwin and Wolf. Our aim was to use this information to make recommendations for enhanced protection during the re-zoning process of the GMR started by the Galapagos National Park Directorate in 2015.

\section{Materials and Methods}

This research was approved by the Galapagos National Park Directorate (GNPD) as part of the 2013 and 2014 annual operational plan of the Charles Darwin Foundation.

\section{Site description}

Darwin and Wolf are the two northernmost islands in the Galapagos Archipelago, a group of 13 major islands and 100 islets and rocks located $1000 \mathrm{~km}$ west of mainland Ecuador, in the ETP (Snell, Stone \& Snell, 1996) (Fig.1). The Galapagos Archipelago lies at the congruence of three major oceanic currents, which provides a highly dynamic and unique oceanographic settings (Palacios, 2004). Darwin and Wolf represent the far northern biogeographic region of the archipelago and are heavily influenced by the warm Panama current that comes from the Northeast, which supports sub-tropical marine communities to these islands (Edgar et al., 2004; Acuña-Marrero \& Salinas-de-León, 2013). Darwin and Wolf are small (approximately 1 and 2 $\mathrm{km}^{2}$, respectively) and represent the tops of eroded, extinct submerged volcanoes, which rose from the surrounding seafloor $>2000 \mathrm{~m}$ below (McBirney \& Williams, 1969; PeñaherreraPalma, Harpp \& Banks, 2013). Darwin and Wolf are exposed to a predominant north-western water flow that supports a unique pelagic assemblage on the south-eastern portions of these islands (Hearn et al., 2010). In contrast to much of the Galapagos, which is dominated by the cold equatorial counter-current, the waters of Darwin and Wolf range from 22.5 to $29^{\circ} \mathrm{C}$ throughout the year, peaking during February-March (Banks, 2002). Two different seasons have been reported around Darwin and Wolf islands: a warm season from January to June, and a cool season from July to December, where mean sea surface temperature remains below $25^{\circ} \mathrm{C}$ (Acuña-Marrero et al., 2014). 
118 In this study, and for comparisons with other reefs worldwide, we treat Darwin and Wolf as a single ecological unit because of the following reasons. First, a number of published studies

120 (Hearn et al. 2010; Ketchum et al. 2014) show that animals in Galápagos (especially 121 hammerhead sharks) frequently move between islands during the cold season (July-December).

122 Second, the two islands are a unique bioregion within the Galapagos Marine Reserve: the 'far 123 north' (Edgar et al. 2004). These two islands are characterized by the influence of the tropical 124 Panama current and support unique fish communities within the Galapagos Marine Reserve. 125 Third, the islands are located less than $40 \mathrm{~km}$ apart, and isolated from the rest of the archipelago 126 (Fig. 1).

\section{Data collection}

\section{Underwater census using Diver Operated Stereo-video}

129 A diver operated stereo-video system (DOV) was used to sample fish assemblages around 130 Darwin and Wolf over two consecutive years $(2013,2014)$ during the cold season that spans 131 from July to December. DOVs use two Canon HFG-25 full high-definition cameras mounted 0.7 $132 \mathrm{~m}$ apart on a base bar inwardly converged at seven degrees and are operated by experienced divers using standard open-circuit SCUBA equipment. DOVs can overcome some of the biases associated with Underwater Visual Census (UVC) by eliminating the inter-observer effect and the over/underestimation of sampling area and fish lengths estimations (Harvey, Fletcher \& Shortis, 2001, 2002; Harvey et al., 2003, 2004; Goetze et al., 2015).

137 Fishes were surveyed at seven sites around Wolf $(n=4)$ and Darwin $(n=3)$ islands (Fig. 1) in 138 November 2013 and August 2014. All sites were coastal rocky reefs and were selected based on 139 their similar structure to be comparable. At each site, divers towed a surface buoy equipped with a GPS (Garmin GPSmap 78) to create a detailed track of the area surveyed, with GPS position and exact time recorded using a watch synchronized with the GPS at the beginning and end of each survey (Schories \& Niedzwiedz, 2012). Divers followed the $20 \mathrm{~m}$ depth contour for a period of 25-30 min in order to complete a minimum of ten $50 \mathrm{~m}$ long and $5 \mathrm{~m}$ wide replicate transects at each site. Dive times were based on preliminary surveys that revealed that swimming at a constant speed, a 2-minute DOVS survey covered approximate $50 \mathrm{~m}$. At some sites, strong currents resulted in longer distances covered by the survey team, resulting in a greater area surveyed. The diver towing the GPS also conducted standard UVCs to record sharks and large pelagics $(50 \times 5 \times 5 \mathrm{~m})$ in parallel to the stereo surveys, therefore the 2-minute surveys were also used to synchronize both sampling methodologies (Supplementary Information). 

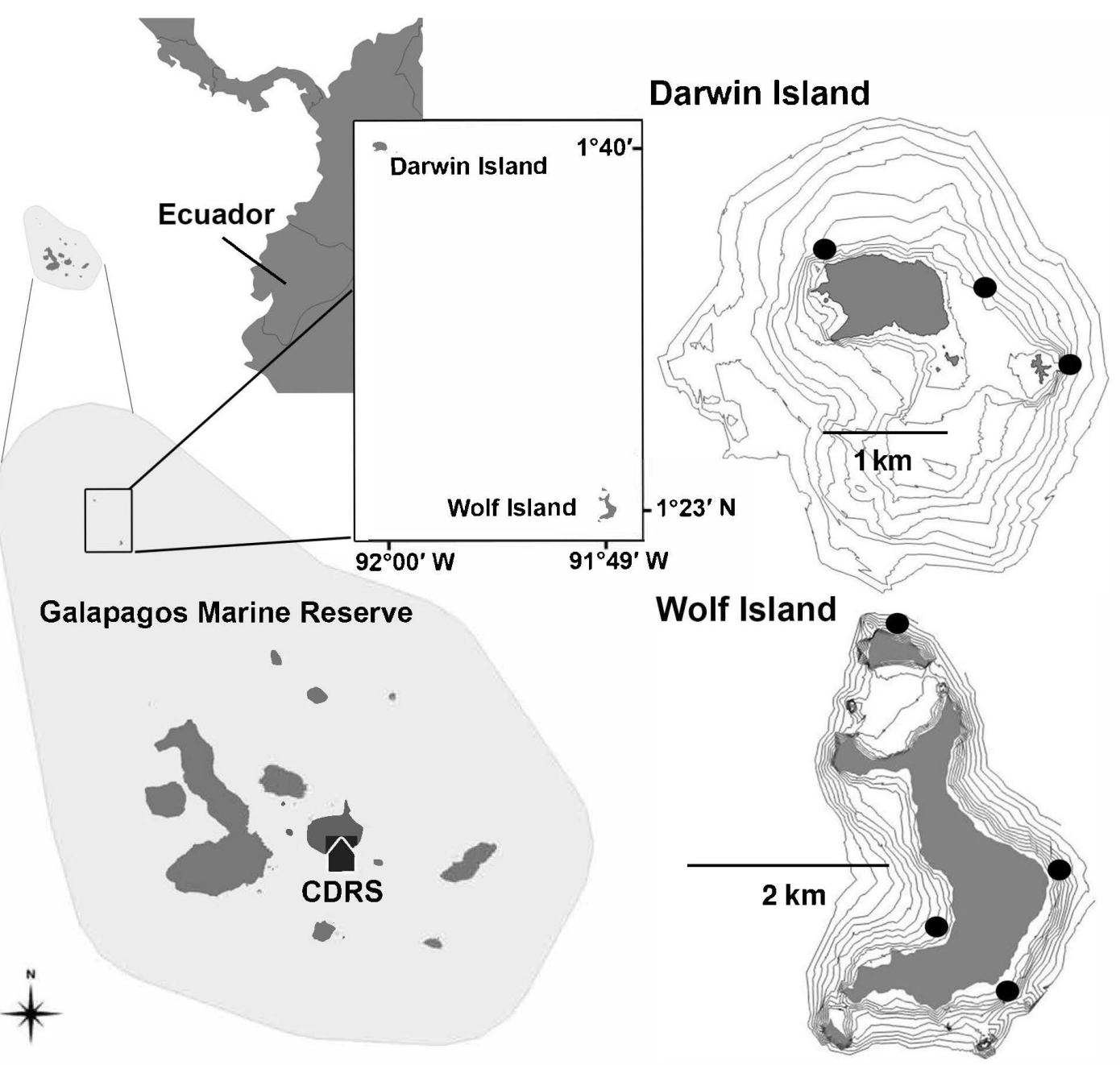

Figure 1. Location of Darwin and Wolf Islands within the Galapagos Marine Reserve, which encompasses the waters 40 nautical miles around the islands. Black dots around Darwin $(n=3)$ and Wolf $(n=4)$ islands are survey sites. CDRS: Charles Darwin Research Station.

\section{Calibration and video analysis}

155 Stereo-video cameras were calibrated prior to field deployments using the program CAL 156 (SeaGIS Pty Ltd; Harvey \& Shortis, 1998). Following the dives, paired videos were viewed on a 157 large monitor and analysed in the program Event Measure (SeaGIS Pty Ltd). Every fish observed 158 was identified to species and measured to the nearest mm (Fork Length, FL). Lengths were converted to biomass $(\mathrm{kg})$ using published length-weight relationships (Froese \& Pauly, 2007). For individual fishes that were not measured (e.g., two individuals overlapping), we calculated biomass using an average total length for that species from the site where it occurred. Cryptic reef fishes $(<8 \mathrm{~cm})$ were excluded from our surveys due to the limited ability of the DOVs to detect these species and their lack of importance to the fisheries and overall biomass (Ackerman $\&$ Bellwood, 2000). Fishes were classified into four different trophic categories based on published information: apex predators, lower-level carnivores, planktivores and herbivores (Friedlander \& DeMartini, 2002b). 
167 For largely abundant schooling fishes, primarily the abundant planktivorous species locally 168 known as gringo (Paranthias colonus), which form dense schools that are difficult to quantify, 169 we developed a specific methodology in the software Event Measure. For each of the study sites 170 surveyed, we measured to the nearest $\mathrm{mm}$ a subsample of 100 individuals across all replicate 171 transects and obtained a specific set of mean individual lengths. Then, transects were divided 172 into blocks of identical length using the GPS tracks and every individual for each $10 \times 5 \times 5 \mathrm{~m}$ wide 173 'cube' was counted. The number of cubes varied according to transect lengths. Total biomass for 174 these sites were obtained by multiplying the total numbers of individuals counted in each cube 175 by the mean individual length for each species at that site.

176 We also conducted a comparative analysis between the traditional survey technique based on 177 underwater visual censuses (UVC) and Diver Operated Video surveys (DOVs) using stereo178 cameras to test for differences in estimates of shark diversity, abundance, and size (Text_S1). A 179 diver with $>5$ years experience in conducting visual surveys of sharks swam alongside a diver 180 conducting video surveys. Both divers were synchronized to conduct the same transect in

181

182

183

184

185

186

187

188

189

190

191

192

193

194

195

196

197

198

199

200

201

202

203

204

205

206

207

208

209 parallel. Synchronization was achieved by conducting 2-minute surveys. This time period was based on a previous archipelago-wide survey $(\mathrm{n}=81$ sites at $20 \mathrm{~m})$ that showed that divers swimming at a constant speed covered an area of approximately $50 \mathrm{~m}$ during a 2-minute time period (Salinas de León, unpublished data). A 15-second interval between transects was used to ensure independence between samples. The visual observer recorded individual shark species, size (FL), and sex of all sharks observed within a $5 \mathrm{~m}$ wide by $5 \mathrm{~m}$ high transect in front of the divers. Transect length was obtained by towing a GPS and dividing the GPS tracts into 2 minutes blocks, with a 15s space between transects. We conducted a total of 69 transects across the seven study sites, covering a total area of $21,700 \mathrm{~m}^{2}$. Strong currents resulted in longer transects than previously estimated and mean transect length across study sites was $65.7 \mathrm{~m}( \pm 2.2 \mathrm{SE})$. Transect length was not significantly different between sampling sites (ANOVA, $\mathrm{p}>0.05$ ).

\section{Statistical tests}

Patterns of total fish biomass and biomass without sharks between islands, wave exposures, and years were analyzed using generalized linear mixed models (Zuur, 2009) using the glmmADMB package (Skaug \& Fournier, 2004) in the R statistical program version 3.0.2 (R Development Core Team). Due to the skewed nature of our biomass estimates, data were fit with a gamma error structure with an inverse link function that works well for continuous-positive data and has a flexible structure (Crawley, 2011). Islands, orientation, and year were all treated as fixed effects, while location (survey site) was used as a random effect in the model. Biomass by trophic group was assessed in a similar manner, except that data were fitted to negative binomial distributions due to the number of zero in these data. Unplanned post hoc multiple comparisons were tested using a Tukey's honestly significant difference (HSD) test. Values in the results are means and one standard deviation of the mean unless otherwise stated. Comparisons between overall relative abundance and biomass recorded by UVC and DOVs were conducted using Wilcoxon rank sum tests.

Similarity of Percentages (SIMPER) in Primer 6.0 (Clarke \& Gorley, 2006) was used to determine the fish species most responsible for the percentage dissimilarities between exposures using Bray-Curtis similarity analysis of hierarchical agglomerative group average clustering 
210 (Clarke, 1993). Differences in fish trophic biomass between islands, years, and wave exposures 211 were tested using permutation-based multivariate analysis of variance (PERMANOVA, Primer 212 v6.0, Clarke and Gorley, 2006). All factors and their interactions were treated as fixed effects. 213 Trophic biomass data were 4th-root-transformed. Post hoc pair-wise tests were conducted 214 between island, wave exposure, and year combinations. Interpretation of PERMANOVA results 215 was aided using individual analysis of similarities (ANOSIM).

216 To describe the pattern of variation in fish trophic structure and their relationship to 217 environmental factors we performed direct gradient analysis (redundancy analysis: RDA) using 218 the ordination program CANOCO for Windows version 4.0 (TerBraak, 1994). Response data 219 were compositional and had a gradient $<3$ SD units long, so linear methods were appropriate. 220 The RDA introduces a series of explanatory (environmental) variables and resembles the model of multivariate multiple regression, allowing us to determine what linear combinations of these environmental variables determine the gradients. The environmental data matrix included island (Darwin, Wolf), wave exposure (NW, SE), and year (2013, 2014). To rank environmental variables in their importance for being associated with the structure of the assemblages, we used a forward selection where the statistical significance of each variable was judged by a MonteCarlo permutation test (TerBraak \& Verdonschot, 1995). Permutations tests were unrestricted with 499 permutations.

\section{Results}

229 Grand mean fish biomass between islands, years, orientation, and locations was $17.5 \mathrm{t} \mathrm{ha}^{-1}( \pm$ 18.6 SE) and was 90\% higher at Darwin $(24.0 \pm 20.8)$ compared with Wolf $(12.6 \pm 16.4)$, although this difference was not significant (Fig. 2, Table 1). Biomass in the SE sections of both islands combined $(26.9 \pm 35.2)$ was more than 6 times higher than in the NW (4.4 \pm 5.9$)$. Biomass was similar between years $(2013=19.3 \pm 18.9 ; 2014=15.6 \pm 19.5)$ but was significantly different due to the large year $\mathrm{x}$ orientation owing to higher biomass in the NW in 2013 at both islands (Fig. 2, Table 1).

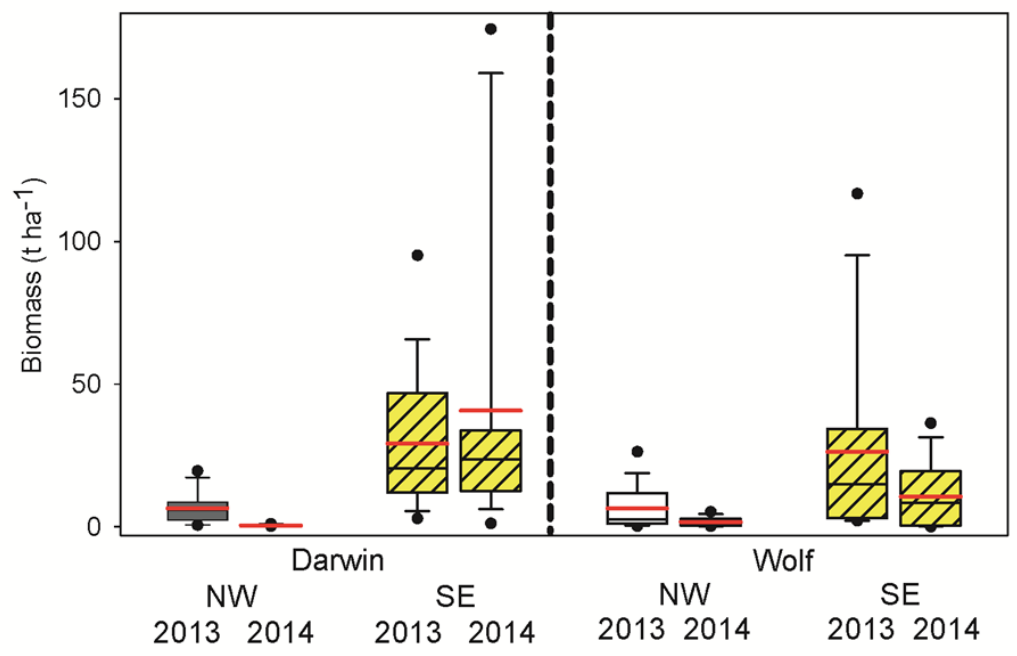


Figure 2. Comparisons of total fish biomass by island, orientation, and year. Box plots showing median (black line), mean (red line), upper and lower quartiles, and 5th and 95th percentiles.

Table 1. Comparisons of total fish biomass by island, orientation and year. Results of generalized linear mixed models fit with a gamma error structure and an inverse link function. Unplanned post hoc multiple comparisons tested using a Tukey's honestly significant difference (HSD) test. Only significant multiple comparisons are shown.

\begin{tabular}{lccccl}
\hline Factor & Estimate & $\begin{array}{c}\text { Std. } \\
\text { Error }\end{array}$ & $\mathrm{Z}$ & $\mathrm{P}$ & Multiple comparisons \\
\hline Island & 0.031 & 0.099 & 0.31 & 0.757 & \\
Orientation & 0.258 & 0.103 & 2.51 & $0.012^{*}$ & $\mathrm{SE}>\mathrm{NW}$ \\
Year & 0.435 & 0.117 & 3.72 & $<0.001^{* * *}$ & $2013>2014$ \\
Orientation x & 0.449 & 0.116 & 3.88 & $<0.001^{* * *}$ & SE13=SE14 $>$ NW13 $>$ NW14 \\
year & & & & & \\
\hline
\end{tabular}

Nearly $73 \%$ of the total biomass $\left(12.4 \pm 4.01 \mathrm{t} \mathrm{ha}^{-1}\right)$ was accounted for by sharks, primarily hammerheads (Sphryna lewini - 48.0\%), Galapagos (Carcharhinus galapagensis - 19.4\%), and blacktips (Carcharhinus limbatus - 5.1\%). Hammerheads occurred on $92 \%$ of transects at SE Darwin, 59\% at SE Wolf, and 9\% at both NW Darwin and Wolf. Gringos (Paranthias colonus) were the third most abundant species by weight, accounting for an additional $18.3 \%$ of the total biomass. They were 2.2 times more abundant by weight in $2013(3.8 \pm 4.1)$ compared with 2014 $(1.7 \pm 2.4)$. Gringos were $48 \%$ more abundant in the SE $(3.5 \pm 3.5)$ compared with the NW $(2.4$ \pm 3.7 ) exposures. The average dissimilarity between orientations was $84 \%$, with hammerhead sharks accounting for $41.6 \%$ of the dissimilarity, followed by gringos (24.2\%), Galapagos sharks $(12.8 \%)$, and blacktip sharks (3.4\%) (Table 2).

Table 2. Fish species most responsible for the dissimilarity between northwest (NW) and southeast (SE) orientations based on Similarity of Percentages (SIMPER) analysis.

\begin{tabular}{|c|c|c|c|c|c|}
\hline Species & $\mathrm{SE}$ & NW & Dissim. & $\begin{array}{l}\% \\
\text { contrib. }\end{array}$ & $\begin{array}{l}\text { Cumulative } \\
\% \text { contrib. }\end{array}$ \\
\hline Sphyrna lewini & 15.06 & 0.7 & $35.0(1.2)$ & 41.6 & 41.6 \\
\hline Paranthias colonus & 3.55 & 2.4 & $20.3(1.0)$ & 24.2 & 65.8 \\
\hline $\begin{array}{l}\text { Carcharhinus } \\
\text { galapagensis }\end{array}$ & 4.66 & 0 & $10.8(0.5)$ & 12.8 & 78.6 \\
\hline Carcharhinus limbatus & 1.77 & 0 & $2.9(0.2)$ & 3.4 & 82.0 \\
\hline Caranx melampygus & 0.58 & 0.08 & $2.1(0.3)$ & 2.5 & 84.5 \\
\hline Lutjanus argentiventris & 0.31 & 0.07 & $1.3(0.4)$ & 1.5 & 86.0 \\
\hline Lutjanus novemfasciatus & 0.18 & 0.02 & $1.0(0.3)$ & 1.2 & 87.2 \\
\hline Holacanthus passer & 0.06 & 0.12 & $1.0(0.3)$ & 1.2 & 88.4 \\
\hline Prionurus laticlavius & 0.05 & 0.07 & $0.9(0.4)$ & 1.1 & 89.5 \\
\hline Sufflamen verres & 0.02 & 0.06 & $0.8(0.3)$ & 1.0 & 90.4 \\
\hline
\end{tabular}


259 Our comparison between underwater visual censuses (UVC) and diver operated video surveys 260 (DOVS) showed that both methods recorded the same number of species $(\mathrm{n}=4)$. Abundance of 261 sharks recorded by DOVs was $1.18 \pm 0.35100 \mathrm{~m}^{-2}$ (mean $\pm \mathrm{SE}$ ), and $0.97 \pm 0.29$ ind. $100 \mathrm{~m}^{-2}$ by $262 \mathrm{UVC}$, and they were not significantly different $(\mathrm{W}=2279$; $\mathrm{p}$-value $=0.619)$. Overall shark biomass 263 recorded was not significantly different between methods $(\mathrm{W}=2341$; $\mathrm{p}$-value $=0.421)$, despite a $57 \%$ higher biomass recorded with DOVs $\left(12.40 \pm 4.01 \mathrm{tha}^{-1}\right)$ compared to UVC $(7.89 \pm 2.05 \mathrm{t}$ $\mathrm{ha}^{-1}$ ). DOVS yielded estimates of shark size significantly larger than visual surveys, which suggests that even experienced observers tend to underestimate shark lengths, particularly for the larger size classes (Fig. S1).

Fish biomass excluding sharks was $4.3 \mathrm{t} \mathrm{ha}^{-1}( \pm 5.1)$, and was $68 \%$ higher at Darwin $(5.8 \pm 5.3)$ compared with Wolf $(3.4 \pm 4.8)$ but not significantly different between islands (Table 2). Exposure showed no significant difference in fish biomass without sharks, but was $58 \%$ higher at the SE $(5.4 \pm 5.3)$ compared to the NW $(3.4 \pm 4.7)$ exposures. Biomass without sharks was $67 \%$ higher in $2013(5.2 \pm 5.3)$ compared to $2014(3.1 \pm 4.5)$ but there was a significant interaction of year with wave exposure (Table 3 ).

Table 3. Comparisons of fish biomass without sharks by island, orientation and year. Results of generalized linear mixed models fit with a gamma error structure and an inverse link function. Unplanned post hoc multiple comparisons tested using a Tukey's honestly significant difference (HSD) test. Only significant multiple comparisons are shown. Exposure $\mathrm{x}$ year factors with the same letter are not significantly different $(\alpha=0.05)$.

\begin{tabular}{|c|c|c|c|c|c|}
\hline Factor & Estimate & $\begin{array}{l}\text { Std. } \\
\text { Error }\end{array}$ & $\mathrm{Z}$ & $P$ & Multiple comparisons \\
\hline Island & 0.092 & 0.191 & 0.48 & 0.631 & \\
\hline Orientation & 0.177 & 0.200 & 0.89 & 0.376 & \\
\hline Year & 0.366 & 0.109 & 3.35 & $<0.001$ & $13>14$ \\
\hline \multirow{2}{*}{$\begin{array}{l}\text { Orientation } \\
\text { x year }\end{array}$} & 0.281 & 0.109 & 2.58 & $0.009 * *$ & 13SE 14NW 14SE 14NW \\
\hline & & & & & $\mathrm{A} \quad \mathrm{AB}$ \\
\hline
\end{tabular}

Apex predators (sharks, jacks, and groupers) accounted for $75 \%$ of the total biomass, followed by planktivores (primarily gringos) at $20 \%$, lower level carnivores $(4 \%)$, and herbivores $(1 \%)$. Apex predator biomass was similar among years with a $27 \%$ difference (Table $4 \mathrm{~A}$ ). Darwin harbored apex predator biomass 2.7 times higher than Wolf, although these differences were not significant. Apex predator biomass was 24 times higher in the SE vs. NW orientations, and although results are suggestive, they were not significantly different owing to the high variance within orientations (NW COV $=271.6, \mathrm{SE} \mathrm{COV}=155.5)$.

Biomass of planktivores was 2.5 times greater, and significantly so, in 2013 (4.5 \pm 4.3 ) compared with $2014(1.8 \pm 2.4)$ (Table 4B). It was 79\% higher at Darwin compared with Wolf and 29\%

292 . 
293 higher in the SE vs. NW, and 46\% higher at Wolf compared with Darwin, although none of these 294 comparisons were significant. Herbivore biomass was 97\% higher in the NW vs. SE, 39\% higher 295 in 2014 vs. 2013, and 74\% higher at Wolf compared with Darwin, but none of these factors was 296 significant.

297 Table 4. Comparisons of biomass among trophic groups by island and orientation. Results of 298 generalized linear mixed models fit with negative binomial error structure. Unplanned post hoc 299 multiple comparisons tested using a Tukey's honestly significant difference (HSD) test. Only 300 significant multiple comparisons are shown.

\begin{tabular}{lllll}
\hline A. Apex predators & Estimate & Std. Error & $\mathrm{Z}$ & $\mathrm{P}$ \\
\hline Island & 0.673 & 0.692 & 0.97 & 0.33 \\
Orientation & 3.071 & 1.731 & 1.77 & 0.07 \\
Year & 0.001 & 0.650 & 0.01 & 0.99 \\
\hline B. Planktivores & Estimate & Std. Error & $\mathrm{Z}$ & $\mathrm{P}$ \\
\hline Island & 0.339 & 0.291 & 1.17 & 0.24 \\
Orientation & 0.284 & 0.297 & 0.96 & 0.33 \\
Year & 0.609 & 0.302 & 2.02 & $0.04^{*}$ \\
\hline C. Carnivores & Estimate & Std. Error & $\mathrm{Z}$ & $\mathrm{P}$ \\
\hline Island & 0.496 & 0.714 & 0.69 & 0.49 \\
Orientation & 0.705 & 0.714 & 0.99 & 0.32 \\
Year & 0.681 & 0.711 & 0.96 & 0.34 \\
\hline D. Herbivores & Estimate & Std. Error & $\mathrm{Z}$ & $\mathrm{P}$ \\
\hline Island & 0.435 & 1.022 & 0.43 & 0.67 \\
Orientation & 0.662 & 0.992 & 0.67 & 0.50 \\
Year & 0.427 & 0.941 & 0.45 & 0.65
\end{tabular}

The structure of the fish assemblage at Darwin and Wolf based on the biomass of each trophic group was influenced by year, island, and orientation, as well as their interactions except for year $\mathrm{x}$ island (Table 5). Orientation (ANOSIM $\mathrm{R}=0.39, \mathrm{p}=0.001)$, followed by year $(\mathrm{R}=0.09, \mathrm{p}=$ $0.001)$ appeared to have the strongest influence on trophic assemblage structure. Crossed ANOSIM between orientation and year yielded $\mathrm{R}=0.41, \mathrm{p}=0.001$ for orientation and $\mathrm{R}=0.14$, $\mathrm{p}=0.001$ for year. Crossed ANOSIM between orientation and island yielded $\mathrm{R}=0.39, \mathrm{p}=0.001$ 309 for orientation and $\mathrm{R}=0.04, \mathrm{p}=0.038$ for island.

310 Table 5. PERMANOVA of drivers of the structure of fish assemblage at Darwin and Wolf based 311 on the biomass of each trophic group (apex predators, planktivores, lower-level carnivores, and 312 herbivores). Only significant interactions are shown.

\begin{tabular}{lcrrrc}
\hline Source & df & \multicolumn{1}{c}{ SS } & MS & Pseudo-F & P \\
\hline Year & 1 & 17232 & 17232.0 & 17.024 & 0.001 \\
Island & 1 & 3058 & 3058.4 & 3.022 & 0.027 \\
Orientation & 1 & 54298 & 54298.0 & 53.642 & 0.001 \\
Year x orientation & 1 & 7384 & 7383.9 & 7.295 & 0.001 \\
Island x orientation & 1 & 4006 & 4005.5 & 3.957 & 0.010
\end{tabular}




\begin{tabular}{lrrrrr}
$\begin{array}{l}\text { Year } \mathrm{x} \text { island } \mathrm{x} \\
\text { orientation }\end{array}$ & 1 & 4345 & 4345.1 & 4.293 & 0.005 \\
$\begin{array}{l}\text { Residual } \\
\text { Total }\end{array}$ & 129 & 130580 & 1012.2 & & \\
\hline
\end{tabular}

314 The first two axes of the RDA bi-plot explained 39\% of the functional group variance and $99 \%$ 315 of the functional group-environment relationship (Table 6, Fig. 3). Orientation explained 87.5\% 316 of the total variance, followed by year $(10.6 \%)$, and island $(9.3 \%)$. Orientations were well 317 separated in ordination space with the SE orientation strongly correlated with apex predator 318 biomass, while NW orientations were influenced by carnivore and herbivore biomass. 319 Planktivore biomass was orthogonal to the other three trophic groups and drove the separation 320 between years.

321 Table 6. A. Results of redundancy analysis (RDA) on square root transformed fish trophic 322 biomass with environmental variables (e.g., island, orientation). B. Conditional effects of Monte323 Carlo permutation results on the redundancy analysis (RDA).

\begin{tabular}{lcrc}
\hline A. Statistic & Axis 1 & Axis 2 & \multicolumn{1}{c}{ Axis 3 } \\
\hline Eigenvalues & 0.34 & 0.04 & 0.01 \\
Pseudo-canonical correlation & 0.67 & 0.46 & 0.20 \\
Explained variation (cumulative) & 34.42 & 38.68 & 38.87 \\
Explained fitted variation (cumulative) & 88.54 & 99.51 & 100.00 \\
\hline B. Variable & Pseudo-F & p & $\%$ explained \\
\hline Exposure & 69.6 & 0.002 & 87.5 \\
Year & 5.8 & 0.006 & 10.6 \\
Island & 5.1 & 0.090 & 9.3 \\
\hline
\end{tabular}




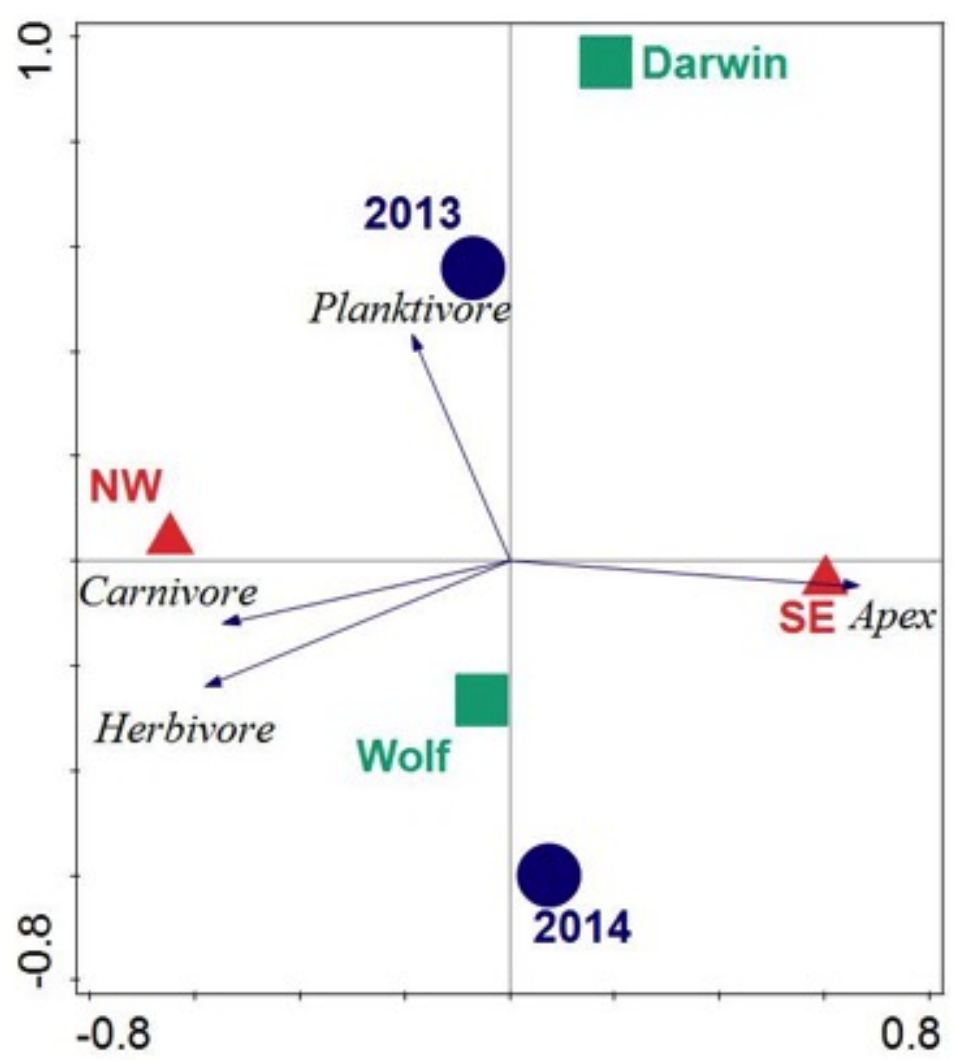

326

327

328

329

330

Figure 3. Bi-plot of results of redundancy analysis of fish trophic biomass with location, wave exposure, and year. Blue circles represent the 2013 and 2014 data. Red triangles are orientations. Squares are centroids of Darwin and Wolf. Vectors are magnitude and directional effects of each trophic group on orientation of locations in ordination space.

\section{Discussion}

The first quantitative fish surveys using the stereo-video approach around Darwin and Wolf islands revealed the largest fish biomass reported to date on a reef worldwide (Fig. 4). This extraordinary biomass, which consists mostly of sharks, is considerably larger than that reported at Cocos Island National Park (Friedlander et al., 2012) and the Chagos Marine Reserve (Graham et al., 2013), the next largest fish biomasses globally.

One potential issue is the comparison of shark biomass results from different methods. We obtained biomass estimates using two methods: underwater visual censuses and video censuses, and found no significant differences between the two methods, despite a $57 \%$ difference in mean biomass between them. This difference is probably due to the large variance in shark biomass values, the small sample size, and the underestimation of shark sizes by visual censuses (Fig. S1). There is no practical way to deal with the issue of small sample size since Darwin and Wolf are small islands, and the availability of comparable sampling habitat is limited. The issue of large variance is also endemic to areas that show large concentrations of top predators in specific 
345

spots, typically exposed and with strong currents (Friedlander et al. 2012; García-Charton et al. 2004; Hearn et al. 2010), making the distribution of top predators highly heterogeneous. In any case, even if the $57 \%$ difference between methods were significant, the shark biomass at Darwin and Wolf $\left(12.4 \mathrm{t} \mathrm{ha}^{-1}\right)$ would still be greater than any other location globally (Cocos Island would be the closest with a re-estimated upper value $7.1 \mathrm{t} \mathrm{ha}^{-1}$ for apex predators).

Our results contribute to the growing body of literature that demonstrates that the least impacted areas are dominated by top predatory fishes, mainly sharks (Friedlander \& DeMartini, 2002b; Sandin et al., 2008; Graham et al., 2013; Friedlander et al., 2013, 2014a). At Darwin and Wolf, top predators account for an astonishing $85 \%$ of the fish biomass, a percentage found previously only at the unfished Kingman Reef on the Line Islands (Sandin et al., 2008). Inverted fish biomass pyramids had been unreported until recent surveys of unfished coral reefs (Sala, 2015). Such inverted biomass pyramids of subsets of ecological communities can be maintained when the top levels of the food web have a much lower turnover rate (slower growth rate per biomass unit) than their prey (Sandin \& Zgliczynski, 2015), and/or when they are subsidized by external energy inputs (Trebilco et al. 2013). In the case of Darwin and Wolf, the large predatory fish biomass might be supported not only by the large abundance of lower trophic levels fish on the reefs but also by the very productive surrounding pelagic waters, where hammerhead and other sharks take daily foraging excursions (Ketchum et al., 2014a,b).

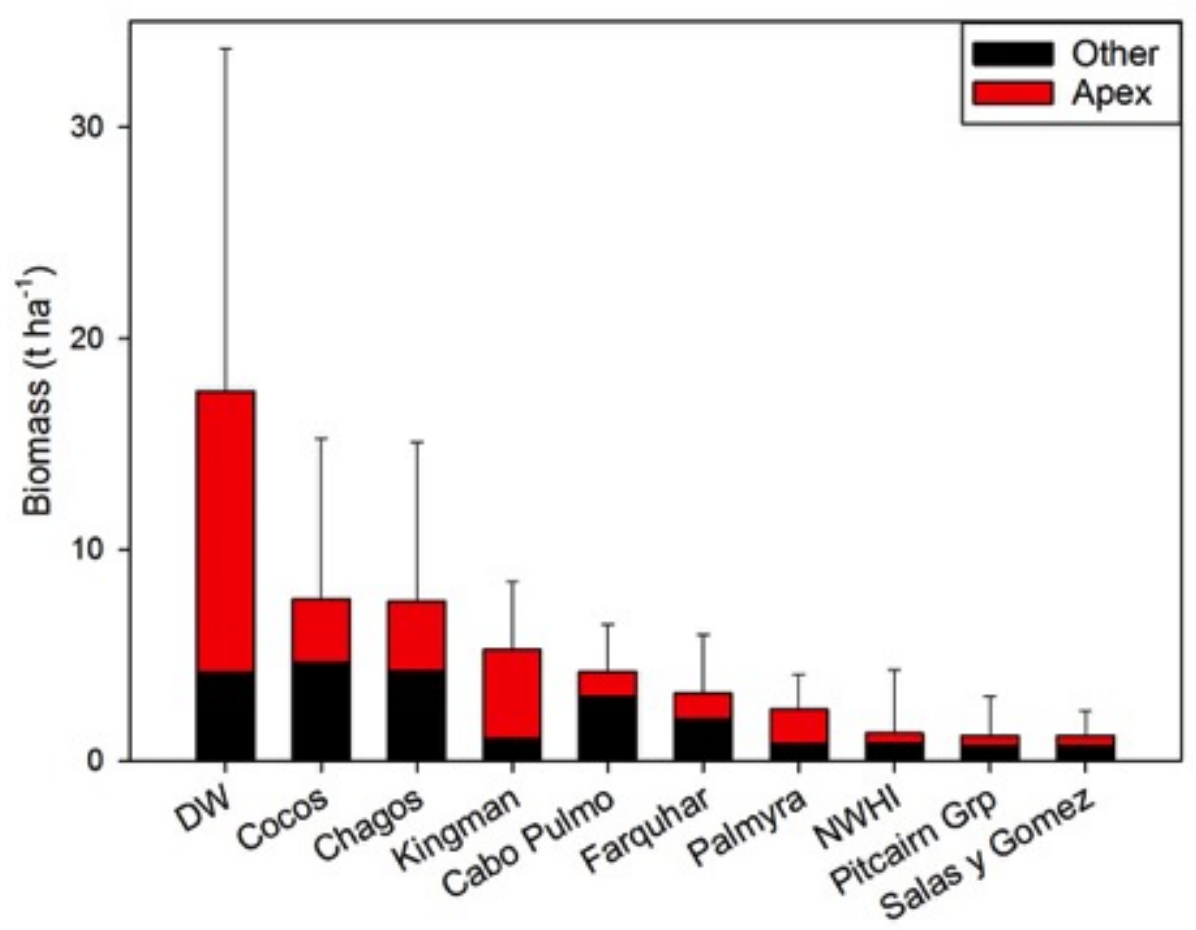

Figure 4. Biomass at Darwin and Wolf compared to other remote locations and no-take marine reserves around the world. Data from (DeMartini et al., 2008; Sandin et al., 2008; Aburto-Oropeza et al., 2011; Friedlander et al., 2012, 2013, 2014a,b; Graham et al., 2013). 
369 Sharks, mainly hammerhead and Galapagos sharks, dominated the fish assemblage, but other predators like the bluefin trevally, black jack (Caranx lugubris) and bigeye jack (C. sexfasciatus) were also common at several of the sites surveyed (Fig.5a-c). Our results revealed a marked concentration of sharks and planktivorous fish biomass at the southeast corners of Darwin and Wolf, something previously documented by acoustic telemetry studies (Hearn et al., 2010; Ketchum et al., 2014b). The higher fish abundance at these SE locations may be related to local oceanographic features, dominated by a unidirectional current from the southeast to the northwest that collides with the southeast corner of both islands (Hearn et al., 2010). This current may enhance productivity that supports rich benthic communities and large numbers of planktivorous fishes, mainly gringos, which may serve as a food source to carnivorous fishes and sharks (Hamner et al., 1988; Hearn et al., 2010). Other proposed hypothesis, include that this area constitutes a vantage location for nightly foraging excursion to adjacent pelagic areas; and/or this area is an important cleaning station (Hearn et al., 2010; Acuña-Marrero et al., 2014; Ketchum et al., 2014b). It is important to consider that these results likely represent maximum annual shark biomass because the surveys were carried out during the cold season (JulyDecember), when hammerhead and other sharks are most abundant (Palacios, 2004; Hearn et al., 2014; Acuña-Marrero et al., 2014; Ketchum et al., 2014b). Seasonal changes in fish assemblages and biomass are likely since hammerheads are known to migrate from these islands between February and June (Ketchum et al., 2014b). Future studies should focus on seasonal trends and depth gradients (Lindfield, McIlwain \& Harvey, 2014) in shark abundance and distribution.

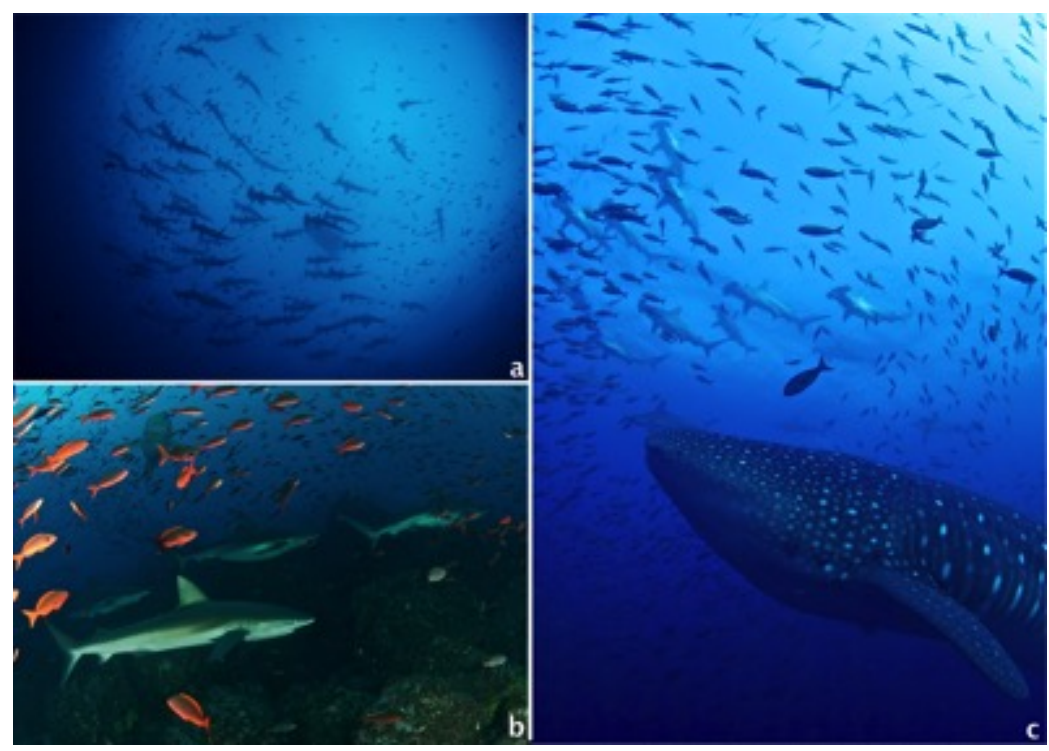

Figure 5 Common encounters around Darwin and Wolf Islands. a) A large school of galapagensis), including a couple of pregnant females; c) A large female whale shark (Rhincodon typus) swims among a school of hammerhead sharks. All photos by Pelayo Salinas394 de-León. 
398

399

400

401

402

403

404

405

406

407

408

409

410

411

412

413

414

415

416

417

418

419

420

421

422

423

424

425

426

427

428

429

430

431

432

433

434

435

436

437

438

439

440

et al., 2013) and recent efforts by local artisanal fishermen to expand longline fishing, a practice banned since 2005 due to large by-catch (Murillo et al., 2004), threaten shark populations. While veteran divers report larger abundance of sharks at Darwin and Wolf 30 years ago (PeñaherreraPalma et al., 2015), the absence of long-term quantitative studies to monitor shark and large pelagic fish on a systematic basis and with enough replication does not allow an accurate assessment of the magnitude of decline of shark populations at Darwin and Wolf. By comparison, the recent analysis of a 21-year monitoring program for sharks and large pelagic fishes at Cocos Island National Park in Costa Rica revealed a sharp decline in 8 of the 12 elasmobranch species monitored, including the endangered hammerhead shark and the giant manta ray (Manta birostris) (White et al., 2015).

Despite the large shark biomass at Darwin and Wolf, our surveys also revealed a low overall biomass of predatory reef fishes such as the leatherbass (Dermatolepis dermatolepis) and the sailfin grouper (Mycteroperca olfax), both endemic to the Eastern Tropical Pacific (ETP) (Grove \& Lavenberg, 1997). These species are highly prized by Galapagos artisanal fishermen, but their life histories (e.g., long lives, slow growing) make them extremely vulnerable to overfishing (Aburto-Oropeza \& Hull, 2008; Usseglio et al., 2015). Leatherbass biomass reported for Darwin and Wolf $\left(0.008 \mathrm{t} \mathrm{ha}^{-1} \pm 0.05 \mathrm{SD}\right)$ is 14 times lower than at the unfished Cocos Island $\left(0.1 \mathrm{t} \mathrm{ha}^{-1}\right)$ (Friedlander et al., 2012). Artisanal fishermen are known to directly target the only reported spawning aggregation for M. olfax in the GMR (Salinas-de-León, Rastoin \& Acuña-Marrero, 2015), an unsustainable fishing practice known to deplete reefs fish stocks at an alarming rate (Sala, Ballesteros \& Starr, 2001; Sadovy \& Domeier, 2005; Erisman et al., 2011; Hamilton et al., 2012). The low biomass estimates for groupers reported here are likely caused by the unregulated artisanal fishery for demersal fishes in the GMR that directly targets over 50 coastal fish species and has been shown to have a negative impact on coastal resources of the GMR (Ruttenberg, 2001; Molina et al., 2004; Burbano et al., 2014; Schiller et al., 2014).

Our results also add to the growing body of literature that supports the use of the stereo video methodology as a complement to traditional visual census, as this technique improves the accuracy and precision of fish length estimates (Harvey, Fletcher \& Shortis, 2001, 2002), produces more accurate estimates of area surveyed (Harvey et al., 2004), and eliminates the inter-observer bias associated with species identification (Mallet \& Pelletier, 2014). Although both stereo-DOVS and UVC recorded a similar number of shark species and overall relative abundance, in our study (one of the few to evaluate the use of DOVs with large and highly mobile species such as sharks), confirmed that even experienced divers tend to underestimate the individual length of large fishes.

\section{Conservation implications}

This study adds to the growing body of literature that highlights the ecological uniqueness and the global irreplaceable value of Darwin and Wolf (Salinas-De-León et al., 2015). These islands not only harbour the largest shark biomass reported to date, but also represent a unique tropical bioregion within the GMR (Edgar et al., 2004). In addition, they are home to the last true coral reefs in the GMR (Banks, Vera \& Chiriboga, 2009; Glynn et al., 2009). These islands also represent essential stepping stones for endangered and highly migratory species, such as hammerhead sharks (Hearn et al., 2010; Bessudo et al., 2011; Ketchum et al., 2014a). They are 
441 key waypoints for a recently documented migration probably related to reproductive purposes for 442 the largest fish species on the planet, the whale shark Rhincodon typus (Acuña-Marrero et al., 443 2014) (Fig. 5d), and are home to the only known reproductive aggregation for the regionally 444 endemic sailfin grouper (Salinas-de-León, Rastoin \& Acuña-Marrero, 2015). These islands are 445 visited by deep-water species such as the smalltooth sandtiger shark Odontaspis ferox (Acuña446 Marrero et al., 2013), and are surrounded by numerous seamounts and active hydrothermal vents 447 that harbour unique biological communities (Salinas-de-León, unpublished data) (Fig. 6).

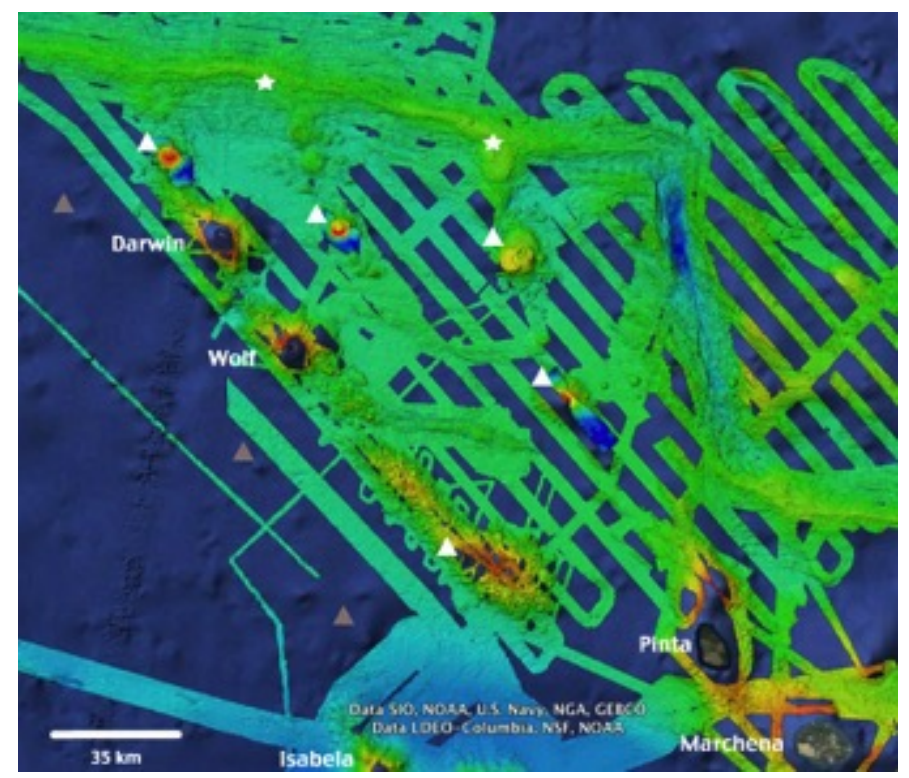

Figure 6. High-resolution bathymetry around Darwin and Wolf Islands. Recent multi-beam echo sounder surveys around D\&W have revealed the presence of a number of seamounts (white triangles) and active hydrothermal vents and black smokers (white stars) that support unique biological communities. Additional inferred seamounts (grey triangles) are likely to be discovered to the West of the Islands. Source: (Dennis et al., 2012), Ocean Exploration Trust NA-064 2015.

The economic benefits of ecotourism from sharks are far greater than shark fishing (Clua et al., 2011; Gallagher \& Hammerschlag, 2011; Cisneros-Montemayor et al., 2013). For instance, the net present value of the average hammerhead shark at Cocos Island National Park was estimated at $\$ 1.6$ million, compared to the $\sim \$ 200$ that a fisherman obtains by selling a dead shark 460 (Friedlander et al., 2012). In Galapagos, the net present value of a shark to the tourism industry is an astonishing \$5.4 million (Lynham et al., 2015). The value of an individual shark to the tourism industry is $\sim \$ 360,000$ per year, compared to $\$ 158$ obtained from a dead shark (Lynham et al., 2015). That makes sharks alive in Galapagos the most valuable on Earth. Despite their high economic value and iconic importance, only about $50 \mathrm{~km}^{2}$ of the waters around Darwin and Wolf (representing an insignificant $0.04 \%$ of the total GMR area) were fully protected from fishing after the creation of the GMR in 1998.

467 Given the large-scale migrations reported for several shark species around Wolf and Darwin 468 (Bessudo et al., 2011; Ketchum et al., 2014a), and the night foraging excursions by scalloped 
469 hammerhead sharks of up to $\sim 30 \mathrm{~km}$ from shore (Ketchum et al., 2014a), the levels of protection 470 after the creation of the Galapagos Marine Reserve in 1998 were clearly insufficient. The 471 government of Ecuador created a 40,000 $\mathrm{km}^{2}$ no-take reserve (the 'Darwin and Wolf Marine 472 Sanctuary') in March 2016, expanding levels of protection around Darwin and Wolf, including 473 some of the numerous seamounts located around these islands (Fig. 6). This conservation move 474 is critical to ensure the recovery and long-term preservation of one of the most extraordinary 475 marine ecosystems on the planet - and an economic engine for Ecuador.

476

477

478

479

480

481

482

483

484

485

486

487

488

489

490

491

492

493

494

495

496

497

\section{Acknowledgements}

We would like to thank the Charles Darwin Foundation and the Galapagos National Park Directorate for their institutional support to this study. We are grateful to all the staff of the Charles Darwin Research Station that made this study possible. Special thanks to Jennifer Suarez and Jose Feijoo for their field assistance. We are also very grateful to the crew of the MV Queen Mabel expedition yacht for their logistical support. This publication is contribution number 2135 of the Charles Darwin Foundation for the Galapagos Islands.

\section{References}

Aburto-Oropeza O., Erisman B., Galland GR., Mascareñas-Osorio I., Sala E., Ezcurra E. 2011. Large Recovery of Fish Biomass in a No-Take Marine Reserve. PLoS ONE 6:e23601.

Aburto-Oropeza O., Hull PM. 2008. A probable spawning aggregation of the leather bass Dermatolepis dermatolepis (Boulenger) in the Revillagigedo Archipelago, Mxico. Journal of Fish Biology 73:288-295.

Ackerman JL., Bellwood DR. 2000. Reef fish assemblages: a re-evaluation using enclosed rotenone stations. Marine Ecology-Progress Series 206:227-237.

Acuña-Marrero D., Zimmerhackel JS., Mayorga J., Hearn A. 2013. First record of three shark species, Odontaspis ferox, Mustelus albipinnis and Centrophorus squamosus, from the Galápagos Islands. Marine Biodiversity Records 6:e87.

Acuña-Marrero D., Jiménez J., Smith F., Doherty PF., Hearn A., Green JR., Paredes-Jarrín J., Salinas-de-León P. 2014. Whale Shark (Rhincodon typus) Seasonal Presence, Residence Time and Habitat Use at Darwin Island, Galapagos Marine Reserve. PLoS ONE 
498 Acuña-Marrero D., Salinas-de-León P. 2013. New record of two Indo-Pacific reef fish, Caranx 499 ignobilis and Naso annulatus, from the Galapagos Islands. Marine Biodiversity Records $500 \quad 6: \mathrm{e} 74$.

501 AIM. 2000. Resolución No. 011-2000.

502 Babcock RC., Kelly S., Shears NT., Walker JW., Willis TJ. 1999. Changes in community 503 structure in temperate marine reserves. Marine Ecology Progress Series 189:125-134. 504 Babcock RC., Shears NT., Alcala AC., Barrett NS., Edgar GJ., Lafferty KD., McClanahan TR., 505 506 507 Russ GR. 2010. Decadal trends in marine reserves reveal differential rates of change in direct and indirect effects. Proceedings of the National Academy of Sciences 107:18256-

Banks S. 2002. Ambiente físico. In: Reserva Marina de Galápagos. Línea base de biodiversidad. 509 Santa Cruz, Galápagos: Fundacion Charles Darwin y Servicio del Parque Nacional de

511 Banks S., Vera M., Chiriboga A. 2009. Establishing reference points to assess long-term change in zooxanthellate coral communities of the northern Galápagos coral reefs. J. Sci. Conserv. in the Galapagos Islands:43-64.

514 Bascompte J., Melián CJ., Sala E. 2005. Interaction strength combinations and the overfishing of a marine food web. Proceedings of the National Academy of Sciences of the United States of America 102:5443-5447.

517 Baum JK., Myers RA., Kehler DG., Worm B., Harley SJ., Doherty PA. 2003. Collapse and conservation of shark populations in the Northwest Atlantic. Science 299:381-392.

519 Bessudo S., Soler GA., Klimley AP., Ketchum JT., Hearn A., Arauz R. 2011. Residency of the 520 scalloped hammerhead shark (Sphyrna lewini) at Malpelo Island and evidence of 

Fishes 91:165-176.

523 Burbano DV., Mena CF., Guarderas P., Vinueza L., Reck G. 2014. Shifting Baselines in the 524 Galapagos White Fin Fishery, Using Fisher's Anecdotes to Reassess Fisheries 525 Management: The Case of the Galapagos Grouper. In: Denkinger J, Vinueza L eds. The 526 Galapagos Marine Reserve. Cham: Springer International Publishing, 227-246.

527 Cagua EF., Collins N., Hancock J., Rees R. 2014. Whale shark economics: a valuation of $528 \quad$ wildlife tourism in South Ari Atoll, Maldives. PeerJ 2:e515.

529 Carr LA., Stier AC., Fietz K., Montero I., Gallagher AJ., Bruno JF. 2013. Illegal shark fishing in 530 the Galápagos Marine Reserve. Marine Policy 39:317-321.

531 Christie MR., Tissot BN., Albins MA., Beets JP., Jia Y., Ortiz DM., Thompson SE., Hixon MA. 532 2010. Larval Connectivity in an Effective Network of Marine Protected Areas. PLoS ONE 5:e15715.

534 Cisneros-Montemayor AM., Barnes-Mauthe M., Al-Abdulrazzak D., Navarro-Holm E., Sumaila UR. 2013. Global economic value of shark ecotourism: implications for conservation.

537 Clarke KR. 1993. Non-parametric multivariate analyses of changes in community structure. 538 Australian Journal of Ecology 18:117-143.

539 Clarke KR., Gorley RN. 2006. PRIMER version 6: user manual/tutorial. Plymouth, UK: PRIMER-E.

541 Clua E., Buray N., Legendre P., Mourier J., Planes S. 2011. Business partner or simple catch? The economic value of the sicklefin lemon shark in French Polynesia. Marine and Freshwater Research 62:764. 
544 Crawley MJ. 2011. The R book. Chichester: Wiley.

545 Darwin C. 1839. The Voyage of the Beagle.

546 DeMartini E., Friedlander A., Sandin S., Sala E. 2008. Differences in fish-assemblage structure 547 between fished and unfished atolls in the northern Line Islands, central Pacific. Marine $548 \quad$ Ecology Progress Series 365:199-215.

549 Dennis KJ., McClinton JT., White, S., Hoernie K., Mittelstaedt EL., Harpp K. 2012. Bathymetry 550 of the Galápagos Spreading Center from a synthesis of 25 years of ship-based multibeam 551 sonar data. In: San Francisco, CA,.

552 Dicken ML., Hosking SG. 2009. Socio-economic aspects of the tiger shark diving industry 553 within the Aliwal Shoal Marine Protected Area, South Africa. African Journal of Marine

555 Dulvy NK., Baum JK., Clarke S., Compagno LJV., Cortés E., Domingo A., Fordham S., Fowler 556 S., Francis MP., Gibson C., Martínez J., Musick JA., Soldo A., Stevens JD., Valenti S. 2008. You can swim but you can't hide: the global status and conservation of oceanic pelagic sharks and rays. Aquatic Conservation: Marine and Freshwater Ecosystems $18: 459-482$.

Dulvy NK., Fowler SL., Musick JA., Cavanagh RD., Kyne PM., Harrison LR., Carlson JK., Davidson LN., Fordham SV., Francis MP., others 2014. Extinction risk and conservation of the world's sharks and rays. Elife 3:e00590.

563 Eddy TD., Pande A., Gardner JPA. 2014. Massive differential site-specific and species-specific 564 responses of temperate reef fishes to marine reserve protection. Global Ecology and Conservation 1:13-26. 
566 Edgar GJ., Banks S., Fariña JM., Calvopiña M., Martínez C. 2004. Regional biogeography of 567 shallow reef fish and macro-invertebrate communities in the Galapagos archipelago.

569 Edgar GJ., Banks SA., Bessudo S., Cortés J., Guzmán HM., Henderson S., Martinez C., Rivera 570 Journal of Biogeography 31:1107-1124.

574

Edgar GJ., Stuart-Smith RD., Willis TJ., Kininmonth S., Baker SC., Banks S., Barrett NS., 575 F., Soler G., Ruiz D., Zapata FA. 2011. Variation in reef fish and invertebrate communities with level of protection from fishing across the Eastern Tropical Pacific seascape: MPA effectiveness in the eastern Pacific. Global Ecology and Biogeography

Erisman BE., Allen LG., Claisse JT., Pondella DJ., Miller EF., Murray JH., Walters C. 2011. The illusion of plenty: hyperstability masks collapses in two recreational fisheries that

Friedlander AM., Zgliczynski BJ., Ballesteros E., Aburto-Oropeza O., Bolaños A., Sala E. 2012. 584 The shallow-water fish assemblage of Isla del Coco National Park, Costa Rica: structure and patterns in an isolated, predator-dominated ecosystem. Revista de Biología Tropical 60:321-338. 
587 Friedlander AM., Ballesteros E., Beets J., Berkenpas E., Gaymer CF., Gorny M., Sala E. 2013.

588 Effects of isolation and fishing on the marine ecosystems of Easter Island and Salas y

589 Gómez, Chile. Aquatic Conservation: Marine and Freshwater Ecosystems 23:515-531.

590 Friedlander AM., Obura D., Aumeeruddy R., Ballesteros E., Church J., Cebrian E., Sala E.

591 2014a. Coexistence of Low Coral Cover and High Fish Biomass at Farquhar Atoll,

$592 \quad$ Seychelles. PLoS ONE 9:e87359.

593 Friedlander AM., Caselle JE., Ballesteros E., Brown EK., Turchik A., Sala E. 2014b. The Real

594 Bounty: Marine Biodiversity in the Pitcairn Islands. PLoS ONE 9:e100142.

595 Friedlander AM., DeMartini EE. 2002a. Friedlander_DeMartini2002.pdf. MARINE ECOLOGY596 PROGRESS SERIES- 230:253-264.

597 Friedlander AM., DeMartini EE. 2002b. Contrasts in density, size, and biomass of reef fishes 598 between the northwestern and the main Hawaiian islands: the effects of fishing down $599 \quad$ apex predators. Marine Ecology Progress Series 230:e264.

600 Froese R., Pauly D. 2007. FishBase (version 02/2012).

601 Gallagher AJ., Hammerschlag N. 2011. Global shark currency: the distribution, frequency, and 602 economic value of shark ecotourism. Current Issues in Tourism 14:797-812.

603 García-Charton JA, Pérez-Ruzafa Á, Sánchez-Jerez P, Bayle-Sempere JT, Reñones O, and 604 605 Moreno D. 2004. Multi-scale spatial heterogeneity, habitat structure, and the effect of marine reserves on Western Mediterranean rocky reef fish assemblages. Marine biology 606 144:161-182.

607 Glynn PW., Riegl B., Correa AM., Baums IB. 2009. Rapid recovery of a coral reef at Darwin 608 Island, Galapagos Islands. Galápagos Res 66:6-13. 
609 Goetze JS., Jupiter SD., Langlois TJ., Wilson SK., Harvey ES., Bond T., Naisilisili W. 2015.

610 Diver operated video most accurately detects the impacts of fishing within periodically

611 harvested closures. Journal of Experimental Marine Biology and Ecology 462:74-82.

612 Goñi R., Adlerstein S., Alvarez-Berastegui D., Forcada A., Reñones O., Criquet G., Polti S., Cadiou G., Valle C., Lenfant P., Bonhomme P., Pérez-Ruzafa A., Sánchez-Lizaso J., García-Charton J., Bernard G., Stelzenmüller V., Planes S. 2008. Spillover from six

615 western Mediterranean marine protected areas: evidence from artisanal fisheries. Marine

616 Ecology Progress Series 366:159-174.

617

618

619

620

621

622

623

624

625

626

627

628

629

630

631

Graham NAJ., Pratchett MS., McClanahan TR., Wilson SK. 2013. The Status of Coral Reef Fish Assemblages in the Chagos Archipelago, with Implications for Protected Area Management and Climate Change. In: Sheppard CRC ed. Coral Reefs of the United Kingdom Overseas Territories. Dordrecht: Springer Netherlands, 253-270.

Graham NAJ., McClanahan TR. 2013. The Last Call for Marine Wilderness? BioScience $63: 397-402$.

Graham NAJ., Spalding MD., Sheppard CRC. 2010. Reef shark declines in remote atolls highlight the need for multi-faceted conservation action. Aquatic Conservation: Marine and Freshwater Ecosystems 20:543-548.

Grove JS., Lavenberg RJ. 1997. The fishes of the Galapagos Islands. Zoological-RecordVolume-134, Section-15-Pisces:1-863.

Halpern BS., Lester SE., Kellner JB. 2009. Spillover from marine reserves and the replenishment of fished stocks. Environmental Conservation 36:268-276.

Halpern BS., Warner RR. 2002. Marine reserves have rapid and lasting effects. Ecology letters 5:361-366. 
632 Hamilton RJ., Giningele M., Aswani S., Ecochard JL. 2012. Fishing in the dark-local knowledge,

633 night spearfishing and spawning aggregations in the Western Solomon Islands.

634 Biological Conservation 145:246-257.

635 Hamner WM., Jones MS., Carleton JH., Hauri IR., Williams DM. 1988. Zooplankton,

636 planktivorous fish, and water currents on a windward reef face: Great Barrier Reef,

637 Australia. Bulletin of Marine Science 42:459-479.

638 Harvey E., Cappo M., Shortis M., Robson S., Buchanan J., Speare P. 2003. The accuracy and

639 precision of underwater measurements of length and maximum body depth of southern

640 bluefin tuna (Thunnus maccoyii) with a stereo-video camera system. Fisheries Research

$641 \quad 63: 315-326$.

642 Harvey ES., Fletcher D., Shortis MR., Kendrick G. 2004. A comparison of underwater visual

643 distance estimates made by SCUBA divers and a stereovideo system: Implications for

644 underwater visual census of reef fish abundance. Marine and Freshwater Research

$645 \quad 55: 573-580$.

646 Harvey ES., Fletcher D., Shortis MR. 2001. A comparison of the precision and accuracy of

647 estimates of reef-fi sh lengths determined visually by divers with estimates produced by a

648 stereo-video system. Fishery Bulletin - National Oceanic and Atmospheric

649 Administration 99:63-71.

650 Harvey ES., Fletcher D., Shortis MR. 2002. Estimation of reef fish length by divers and by

651 stereo-video A first comparison of the accuracy and precision in the field on living fish

652 under operational conditions. Fisheries Research 57:255-265. 
653 Hearn A., Ketchum J., Klimley AP., Espinoza E., Peñaherrera C. 2010. Hotspots within 654 hotspots? Hammerhead shark movements around Wolf Island, Galapagos Marine 655 Reserve. Marine Biology 157:1899-1915.

656 657 658 659 660 661 662 663 664 665 666 667 668 669 670 671 672 673
Hearn AR., Acuña D., Ketchum JT., Peñaherrera C., Green J., Marshall A., Guerrero M., Shillinger G. 2014. Elasmobranchs of the Galapagos Marine Reserve. In: Denkinger J, Vinueza L eds. The Galapagos Marine Reserve. Cham: Springer International Publishing, 23-59.

Heithaus MR., Wirsing AJ., Dill LM. 2012. The ecological importance of intact top-predator populations: a synthesis of 15 years of research in a seagrass ecosystem. Marine and Freshwater Research 63:1039.

Jackson JBC. 2010. The future of the oceans past. Philosophical Transactions of the Royal Society B: Biological Sciences 365:3765-3778.

Jacquet J., Alava JJ., Pramod G., Henderson S., Zeller D. 2008. In hot soup: sharks captured in Ecuador's waters. Environmental Sciences 5:269-283.

Ketchum JT., Hearn A., Klimley AP., Peñaherrera C., Espinoza E., Bessudo S., Soler G., Arauz R. 2014a. Inter-island movements of scalloped hammerhead sharks (Sphyrna lewini) and seasonal connectivity in a marine protected area of the eastern tropical Pacific. Marine Biology 161:939-951.

Ketchum JT., Hearn A., Klimley AP., Espinoza E., Peñaherrera C., Largier JL. 2014b. Seasonal changes in movements and habitat preferences of the scalloped hammerhead shark (Sphyrna lewini) while refuging near an oceanic island. Marine Biology 161:755-767. 
674 Lester S., Halpern B., Grorud-Colvert K., Lubchenco J., Ruttenberg B., Gaines S., Airamé S.,

675 Warner R. 2009. Biological effects within no-take marine reserves: a global synthesis.

676 Marine Ecology Progress Series 384:33-46.

677 Lindfield SJ., McIlwain JL., Harvey ES. 2014. Depth refuge and the impacts of SCUBA

$678 \quad$ spearfishing on coral reef fishes. PloS one 9:e92628.

679 Lynham J., Costello C., Gaines SD., Sala E. 2015. Economic valuation of marine and shark-

680 based tourisms in the Galápagos Islands. National Geographic Pristine Seas.

681 Mallet D., Pelletier D. 2014. Underwater video techniques for observing coastal marine

682 biodiversity: A review of sixty years of publications (1952-2012). Fisheries Research

$683 \quad 154: 44-62$.

684 McBirney AR., Williams H. 1969. Geology and petrology of the Galapagos Islands. Geological $685 \quad$ Society of America Memoir 118:1-197.

686 McClenachan L., Ferretti F., Baum JK. 2012. From archives to conservation: why historical data

687 are needed to set baselines for marine animals and ecosystems: From archives to

688 conservation. Conservation Letters 5:349-359.

689 Molina L., Danulat E., Oviedo M., González JA. 2004. Guía de especies de interés pesquero en 690 la Reserva Marina de Galápagos.

691 Murillo JC., Reyes H., Zárate P., Banks S., Danulat E. 2004. Evaluación de la captura incidental 692 durante el Plan Piloto de Pesca de Altura con Palangre en la Reserva Marina de 693 Galápagos.

694 Myers RA., Baum JK., Shepard TD., Powers SP., Peterson CH. 2007. Cascading effects and the 695 loss of apex predatory sharks from a coastal ocean. Science 325:1846-1850. 
696 Myers RA., Worm B. 2003. Rapid worldwide depletion of predatory fish communities. Nature

697 423:280-283.

698 Palacios DM. 2004. Seasonal patterns of sea-surface temperature and ocean color around the

700 Galápagos: regional and local influences. Deep Sea Research Part II: Topical Studies in

701

702 evolution 10:430.

703

704

705

706

707

708

709

710

711

712

713

714

715

716

717 Oceanography 51:43-57.

Pauly D. 1995. Anecdotes and the shifting baseline syndrome of fisheries. Trends in ecology and

Peñaherrera-Palma C., Llerena, Y., Espinoza E., Semmens J. 2015. Analysis of the perception of population trends for six shark species in the Galapagos Marine Reserve. In: Galapagos Report 2013-2014. Puerto Ayora, Galapagos, Ecuador: GNPD, GCREG, CDF and GC,.

Peñaherrera-Palma C., Harpp K., Banks S. 2013. Rapid seafloor mapping of the northern Galapagos Islands, Darwin and Wolf. Galapagos Research 68.

Ruttenberg BI. 2001. Effects of artisanal fishing on marine communities in the Galapagos Islands. Conservation Biology 15:1691-1699.

Sadovy Y., Domeier M. 2005. Are aggregation-fisheries sustainable? Reef fish fisheries as a case study. Coral Reefs 24:254-262.

Sala E. 2015. Shifting baselines in coral reef fishes. In: Ecology of Fishes on Coral Reefs. Cambridge: Cambridge University Press,.

Sala E., Ballesteros E., Starr RM. 2001. Rapid decline of Nassau grouper spawning aggregations in Belize: fishery management and conservation needs. Fisheries 26:23-30.

Salinas-De-León P., Acuña-Marrero D., Carrión-Tacuri J., Sala E. 2015. Valor ecológico de los ecosistemas marinos de Darwin y Wolf, Reserva Marina de Galápagos. Puerto Ayora, 

Galápagos.

720 Salinas-de-León P., Rastoin E., Acuña-Marrero D. 2015. First record of a spawning aggregation for the tropical eastern Pacific endemic grouper Mycteroperca olfax in the Galapagos Marine Reserve. Journal of Fish Biology 87:179-186.

Sandin SA., Smith JE., DeMartini EE., Dinsdale EA., Donner SD., Friedlander AM., Konotchick T., Malay M., Maragos JE., Obura D., Pantos O., Paulay G., Richie M., Rohwer F., Schroeder RE., Walsh S., Jackson JBC., Knowlton N., Sala E. 2008. Baselines and Degradation of Coral Reefs in the Northern Line Islands. PLoS ONE 3:e1548. Reefs. Cambridge: Cambridge University Press,.

Schiller L., Alava JJ., Grove J., Reck G., Pauly D. 2014. The demise of Darwin's fishes:

Schories D., Niedzwiedz G. 2012. Precision, accuracy, and application of diver-towed evidence of fishing down and illegal shark finning in the Galápagos Islands. Aquatic Conservation: Marine and Freshwater Ecosystems:n/a-n/a.

\section{4} underwater GPS receivers. Environmental Monitoring and Assessment 184:2359-2372.

\section{6}

Shears N., Babcock R. 2002. Marine reserves demonstrate top-down control of community structure on temperate reefs. Oecologia 132:131-142.

Shears NT., Babcock RC. 2003. Continuing trophic cascade effects after 25 years of no-take marine reserve protection. Marine ecology. Progress series 246:1-16.

Sibaja-Cordero JA. 2008. Tendencias espacio-temporales de los avistamientos de fauna marina en los buceos turísticos (Isla del Coco, Costa Rica). Rev. Biol. Trop 56:113-132. 
740 Skaug HJ., Fournier D. 2004. Automatic approximation of the marginal likelihood in nonlinear

741 hierarchical models. Unpublished available from: http://bemata. imr. no/laplace. pdf.

742 Snell HM., Stone PA., Snell HL. 1996. A summary of geographical characteristics of the

743 Galapagos Islands. Journal of Biogeography 23:619-624.

744 TerBraak CJ. 1994. Canonical community ordination. Part I: Basic theory and linear methods.

$745 \quad$ Ecoscience:127-140.

746 TerBraak CJ., Verdonschot PF. 1995. Canonical correspondence analysis and related

747 multivariate methods in aquatic ecology. Aquatic sciences 57:255-289.

748 Trebilco R, Baum JK, Salomon AK, and Dulvy NK. 2013. Ecosystem ecology: size-based 749 constraints on the pyramids of life. Trends in Ecology \& Evolution 28:423-431.

750 Usseglio P., Friedlander AM., DeMartini EE., Schuhbauer A., Schemmel E., Salinas de Léon P. 751 2015. Improved estimates of age, growth and reproduction for the regionally endemic 752 Galapagos sailfin grouper Mycteroperca olfax (Jenyns, 1840). PeerJ 3:e1270.

753 Vianna GMS., Meeuwig JJ., Pannell D., Sykes H., Meekan MG. 2011. The socio-economic 754 value of the shark-diving industry in Fiji. Perth: University of Western Australia. $26 p$.

755 Vianna GMS., Meekan MG., Pannell DJ., Marsh SP., Meeuwig JJ. 2012. Socio-economic value 756 and community benefits from shark-diving tourism in Palau: A sustainable use of reef shark populations. Biological Conservation 145:267-277.

758 Ward-Paige CA., Mora C., Lotze HK., Pattengill-Semmens C., McClenachan L., Arias-Castro

759 E., Myers RA. 2010. Large-Scale Absence of Sharks on Reefs in the Greater-Caribbean: A Footprint of Human Pressures. PLoS ONE 5:e11968.

761 White ER., Myers MC., Flemming JM., Baum JK. 2015. Shifting elasmobranch community 762 assemblage at Cocos Island-an isolated marine protected area: Elasmobranch Community Shifts. Conservation Biology:n/a-n/a. 
764 Zuur AF. (ed.) 2009. Mixed effects models and extensions in ecology with R. New York, NY:

$765 \quad$ Springer.

766

767 